THE STORY OF THE U.S'S

"In addition to the disturbing influence of racial friction, the nationalist movement in Africa is further harassed by the machinations of international Communism, forever seeking to turn fluid situations to advantage for the Communist bloc." - Joseph C. Satterthwaite, first Assistant Secretary of State of African Affairs, October 1958. [1]

When President Eisenhower created the Bureau for African Affairs within the U.S. State Department in 1958, the intent was clear: to prevent the spread of communism. Never before had there been an office within the U.S. government that was solely responsible for developing U.S. foreign policy towards countries in Africa. The U.S. Bureau for Africa was born from the Cold War, and anti-communist rhetoric shaped much of its early policies. As the U.S. engaged in proxy wars to prevent the spread of communism on the continent, African issues gained a new importance to U.S. foreign policy. However, when the Berlin Wall fell, U.S. diplomatic attention to Africa withered. Throughout the 1990s, the U.S. paid little attention to Africa and the Departments of State and Defense concluded that there were few national interests at stake on the continent. It was not until 9/11 and the Global War on Terror that Africa re-emerged on the policy radar. In the early 2000s, defense studies scholars published literature on the importance of Africa to the Global War on Terror. Additionally, the rise of Chinese involvement on the continent began to gain attention as new natural resources were discovered. African issues were once again thrust into the spotlight as the rise of a new economic power and the presence of ungoverned territories worried U.S. policymakers. The personal convictions of President George W. Bush further played a role in defining U.S. national interests

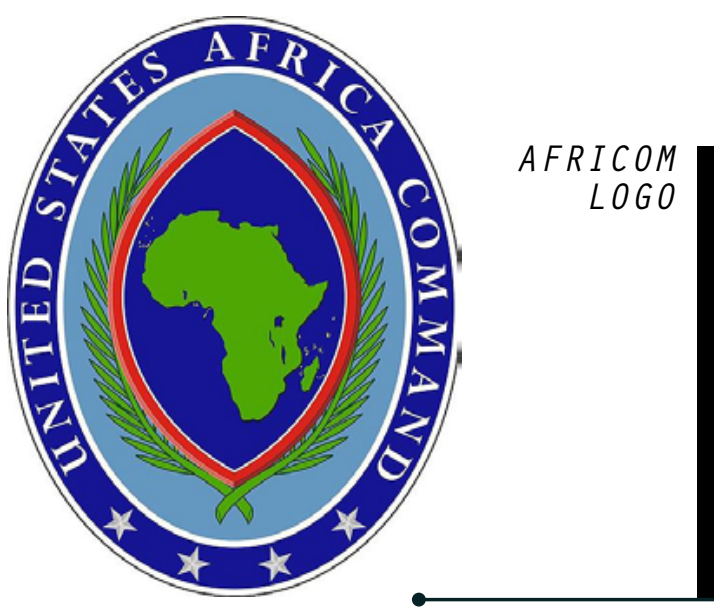


AFRICA OFTEN FELL TO THE PERIPHERY. THIS CAUSED MILITARY EFFORTS IN AFRICA TO BE, AS CONCLUDED BY THEDOD, "REACTIVE, EPISODIC, AND WITHOUT LONG-TERM $S T R A T E G Y^{\prime \prime}$

towards the continent.

On February 6th, 2007, U.S. foreign policy towards Africa saw the creation of another new organization: the U.S. Africa Command (USAFRICOM), a regional military command unit responsible for operations on the African continent. As with the Bureau for African Affairs, the creation of AFRICOM was seen as a shift in U.S. foreign policy towards the continent. Prior to AFRICOM's establishment, responsibility for countries in Africa had been divided amongst three different regional commands. After years of increasing discussion about the effectiveness of this system, Secretary of Defense Donald Rumsfeld commissioned a planning committee to decide the fate of military efforts in Africa. The committee recommended a separate command be established and President Bush signed off on the new Africa Command the day Rumsfeld approached him with the idea. The creation of AFRICOM brought up several key questions about U.S. policy towards Africa as many analysts asked, "Why now?" As the media postulated that Chinese influence and access to natural resources were the driving forces behind AFRICOM's creation, the Department of Defense tried to assuage the controversy claiming that AFRICOM was the logical "next step" needed to enhance the effectiveness of the Global War on Terror.

"There has been much discussion and some debate as to why the command was created at this specific time in our nation's history. From my perspective, it was recognition of Africa's importance in our globalized world." - AFRICOM General William Ward [2]

The Changing Structure of the U.S. MILITARY

In 1946, the Joint Chiefs of Staff inaugurated the Unified Command Plan (UCP), which aimed to increase the efficiency of military planning. As a result of the global warfare in World War II, military planners recognized the need for a unified military presence throughout the world. The UCP intended to consolidate military efforts and de-centralize decision-making as U.S. military presence around the globe grew. [3] Acknowledging the changing nature of the international system, the UCP architects implemented an annual review. As a result, the combatant command system has changed significantly from the original 1946 structure. For example, in 1983 President Reagan authorized the creation of a Central Command (CENTCOM) as a result of rising national interests in the Middle East region. Currently, there are six commands: Northern Command (NORTHCOM), Southern Command (SOUTHCOM), European Command (EUCOM), Central Command (CENTCOM), Pacific Command (PACOM), 
and Africa Command (AFRICOM). Prior to 2007, countries in Africa were split between EUCOM, CENTCOM, and PACOM. Each command, however, focused resources and time on their primary region of responsibility. Africa often fell to the periphery. This caused military efforts in Africa to be, as concluded by the $\mathrm{DoD}$, "reactive, episodic, and without long-term strategy." [4]

BACKGROUND: THE U.S. AND Africa in the 20 th Century

Despite the fact that military efforts in Africa were low priorities for the regional commands, the U.S. had been involved with military training of soldiers on the continent for the past century. In the early 1900s, the U.S. army trained soldiers in Liberia, and during World War II, fought alongside them against axis powers. [5] World War II brought fighting to several other northern African states such as Morocco, Algeria and Tunisia. However, it wasn't until after World War II that the U.S. decided that a foreign policy strategy was needed for the region. In 1958, President Eisenhower established the Bureau for African Affairs within the State Department, creating a staff and an assistant secretary of state whose sole job was U.S. strategy towards Africa. [6]

The creation of the Bureau came at a time when Africa emerged as a proxy battleground for the Cold War. The U.S. and Soviet Union financed rebels on opposite sides of conflicts in Angola, Mozambique, Rhodesia (now Zimbabwe), and Zaire (now the Democratic Republic of Congo). [7] When Donald Rumsfeld became Secretary of Defense for his first time in 1975 under President Ford, rebels supported by the Soviet Union had just recently taken control in Angola. In his memoirs, Rumsfeld attributes this in part to Congress's amendment prohibiting the U.S. from providing financial support to Angola to fight the Marxist rebels.

"While America had been preoccupied in Southeast Asia, the Soviets had broadened their empire-building efforts to nearly every continent in the world. ... Without American assistance to fend off the Marxist rebels, Angola became a communist dictatorship. More worrisome, the Soviet Union came away believing it had a free hand on the continent of Africa." [8]

In the years after, Angola fell into a 27 yearlong civil war, with the U.S., the Soviet Union, and several other countries supporting various rebel groups and sometimes changing allegiances. Often, the nature of the Cold War caused alliances to switch, as the U.S. and Soviet Union supported certain groups in response to the actions of the other. For example, in the Ogaden War between Ethiopia and Somalia, the U.S. had provided aid and weapons to Ethiopia, while the Soviets had maintained a close relationship with Somalia in the early 1970s prior to the war. At the start of the war, several factors caused the U.S. to remove support from Ethiopia. When the Soviets began to supply arms to Ethiopia, the U.S. responded by switching its allegiance to Somalia. [9] U.S. foreign policy towards Africa during the time of the Cold War was dictated by one thing: countering against the Soviets. Strategy was fairly straightforward, as the U.S. simply supported the group fighting the communist or socialist forces supported by the Soviet Union.

However, after the end of the Cold War, national interests in Africa became muddled. There was no apparent enemy to work against and no client states to be sought. Policy-makers were unsure what U.S. interests in the continent were in this new era. In 1995, Department of Defense (DoD) 
analysts concluded that there were few U.S. national interests in Africa. A report rating regions of the world based on their strategic interest to the U.S. published that year listed Africa at the bottom saying, "ultimately, we see very little traditional strategic interest in Africa." [10] This viewpoint persisted for the next several years. President Clinton's 1998 National Security Strategy (NSS) listed Africa last in terms of strategic regions where U.S. national interests were at stake. [11] According to Prudence Bushnell, Deputy in the State Department Africa Bureau in the Clinton administration, this low ranking "was an unspoken mantra by the White House. Africa issues, unless they turned into disasters, seldom made it to the seventh floor, where the top of the hierarchy worked." [12]

Yet, during the Clinton administration there were several efforts with humanitarian military efforts in Africa. The most well known of these occurred Clinton's first year in office, when 19 U.S. soldiers were killed in Somalia. Then in 1994 during the Rwandan genocide, EUCOM was briefly deployed to bring humanitarian supplies to refugee camps. Two years later, a military coup in Burundi and subsequent rise in violence prompted the Clinton administration to propose an African Crisis Response Initiative (ACRI). The aim of ACRI was to set up a multilateral African peacekeeping force supported by the U.S. In Parameters, the quarterly journal of the U.S. Army War College, Dan Henk described ACRI as an example of the "limited and reactive character of U.S. involvement in Africa" [13]. The proposal received an unenthusiastic response from leaders in Africa, but was supported in Europe. In 1997, the initiative began to train militaries in several African countries. [14] Today, ACRI has evolved in the State Departments African Contingency Training Assistance
(ACOTA) program, which trains African soldiers for peacekeeping missions. [15]

The ACRI program spurred an academic discussion about U.S. national interests in Africa among students at the U.S. Army War College, the Army's most senior education institution. More articles and reports such as Dan Henk's, which outlined eleven national interests the U.S. had in Africa, were published. The first report to suggest the creation of a new command solely focused on Africa was by Dr. Lieutenant Colonel William Fox Jr. Fox was a distinguished command surgeon who served in several special operations in Latin America and Africa, as well as a number of complex medical operations in the latter. Lieutenant Colonel Fox wrote a report published by the National Defense University in 1997 calling for the creation of an Africa command. [16] In it, Fox describes the strategy in Africa as reactive rather than proactive and writes,

"DoD can no longer afford simply to wait and react to the next crisis in Africa. A regional command separate from the U.S. European Command or the U.S. Central Command should be established to evaluate, plan and execute regional military exercises and operations." [17]

Several more reports criticized the current UCP and noted the need for a unified command in Africa. As Richard Catoire describes in a Parameters article, a command solely for Africa would "bring the constant attention of senior US military planners to African security issues and facilitate longterm coherent programs to shape the regional environment." [18] Catoire disagreed with the DoD analysis of Africa as a low-priority region saying, "that assertion is itself somewhat puzzling in light of the fact that the United States has intervened militarily in 
the region more than 20 times since 1990." [19]

As this academic discussion continued, U.S. foreign policy towards Africa remained stagnant and the continent continued to be ranked low in terms of strategic interests until after 9/11.

\section{GEORGE W. BUSH}

During the 2000 presidential campaign, George W. Bush seemed to agree with the prevailing opinion on U.S. interests in Africa, yet his first years in office indicate the opposite. During the campaign, Bush criticized Clinton's peacekeeping attempts, saying that the U.S. military shouldn't be involved in nation-building. He argued that "while Africa may be important, it doesn't fit into national strategic interests, as far as I can see them." [20] However, Bush began to emphasize African issues during his first year in office, starting with an increased diplomatic effort to end the civil war in Sudan. [21] Throughout his first term he established more initiatives aimed towards Africa than any president before him, including the President's Emergency Plan for AIDS Relief and the Millennium Challenge Corporation. According to African policy experts at the Center for Strategic International Studies (CSIS), "over time, PEPFAR and MCC became symbols of the value of investing substantially in soft power in Africa, and, in the case of PEPFAR, came to be commonly regarded among the most positive Bush era legacies." [22]

In his memoirs, Bush describes Africa as a personal priority to him. When recounting his early discussions with Secretary of State Condoleezza Rice, he writes:

"One day our conversation turned to Africa. Condi had strong feelings on the subject. She felt Africa had great potential, but had too often been neglected. We agreed that Africa would be a serious part of my foreign policy." [23]

He also wrote that he "considered America a generous nation with a moral responsibility to do our part to help relieve poverty and despair." [24]

During the 2000 campaign, Bush described himself as a 'compassionate conservative,' which garnered him much support from the Christian Right and increased his appeal to moderates. In the campaign, Bush said he would aim to center his presidency on 'compassionate conservativism' ideals and his belief that "it is compassionate to actively help our citizens in need. It is conservative to insist on responsibility and results." [25]

$$
\begin{gathered}
\text { SePtember } 11 \text { Th AND THE } \\
\text { ADVENT OF THE GLOBAL WAR ON } \\
\text { TERRORISM }
\end{gathered}
$$

"The events of $9 / 11$ combined with 20/20 hindsight made clear that Africa was integral, not peripheral, to global security in general, and U.S. security in particular." Assistant Secretary of Defense for African Affairs Theresa Whelan [26]

September 11th transformed the landscape of U.S. foreign policy and led to another turning point for U.S.-Africa relations. As the investigation into Al Qaeda became public, Osama bin Laden's work in Sudan opened many questions about the role of unstable African countries in terrorist activity. The 1998 bombings of U.S. embassies in Kenya and Tanzania had alerted the U.S. to the possibility of terrorism in Africa, but until 9/11 the majority of policymakers didn't think this threat could impact 
SEPTEMBER $11 \mathrm{TH}$

TRANSFORMED THE

LANDSCAPE OF

U.S. FOREIGN

POLICY AND LED

TO ANOTHER

TURNING POINT

FOR U.S.-AFRICA

RELATIONS

the U.S. at home. September 11th shifted this paradigm and Africa gained new importance, which was recognized in the 2004 National Military Strategy:

"There exists an 'arc of instability' stretching from the Western Hemisphere, through Africa and the Middle East and extending to Asia. There are areas in this arc that serve as breeding grounds for threats to our interests." [27]

Part of the strategy to win the war on terror, as discussed in the National Strategy for Combating Terrorism, written by the National Security Council, was to address instability in countries that provides "safehavens" for terrorist activity.

"We will strengthen the capacity of such War on Terror partners to reclaim full control of their territory through effective police, border, and other security forces as well as functioning systems of justice. To further counter terrorist exploitation of under-governed lands, we will promote effective economic development to help ensure long-term stability and prosperity. In failing states or states emerging from conflict, the risks are significant." [28]
Prior to 9/11, Africa's political instability and humanitarian crises were not seen as threats to U.S. national security interests. However, after $9 / 11$, these issues were seen in a new light. Politically unstable areas became known as "ungoverned" or "under-governed" spaces, and it was recognized that the U.S. Global War on Terrorism needed to include these regions.

After 9/11, the U.S. began several initiatives aimed at addressing the threats posed by instability in Africa. Two regions were seen as containing terrorist activity that could threaten U.S. interests: The Sahara/ Sahel region, and the Horn of Africa. In 2002, the U.S. began the Pan-Sahel Initiative (PSI), led by EUCOM. The PSI offered training support to national militaries of countries working to counter radical Islamists in the Sahel, which included Mali, Niger, Chad, and Mauritania. In 2005, this became the Trans Sahara Counter-Terrorism Partnership, and was expanded to include Algeria, Morocco, Senegal, Nigeria, and Tunisia. [30] Two years later, in 2007, this mission became an extension of the Operation Enduring Freedom (OEF), which was the official name for the war in Afghanistan. Earlier that year, a radical Islamist Algerian group operating in the Sahel had pledged allegiance 
to Al-Qaeda and officially changed its name to Al-Qaeda in the Islamic Maghreb (AQIM). [31] AQIM's main activities involve drug and weapons trafficking, kidnapping of westerners for ransom, and small-scale attacks on the Algerian army. OEF-Trans Sahara (OEF-TS) is an ongoing mission working to strengthen states' capacity to counter AQIM through military information sharing, communications system strengthening, logistical support, and training of soldiers. [32]

CENTCOM leads the second OEF extension in Africa, which focuses on the Horn of Africa (HOA) countries Kenya, Somalia, Sudan, Eritrea, Djibouti, Ethiopia, and also Yemen. Unlike OEF-TS, which built on previous initiatives, OEF-HOA began in 2002 to specifically counter the threat of Al Qaeda members fleeing into the Horn from Afghanistan. [33] The primary military component of the mission is the Combined Joint Task Force - Horn of Africa (CJTFHOA), which also began in 2002. When the threat of fleeing Al Qaeda members failed to materialize, the operation shifted focus to training local militaries, supporting humanitarian missions, and working on antipiracy operations. CJTF-HOA has met some controversy, particularly during the 2006 war in Somalia during which there were many civilian casualties. [34]

\section{Secretary of Defense Donald} Rumsfeld believed that building the capacities of governments in African countries was necessary to combat terrorism. In his memoirs he writes of the importance of programs such as the OEF-HOA and PSI.

\footnotetext{
"Terrorists had an easier time indoctrinating, recruiting, training, equipping, raising funds, and planning their attacks when they enjoyed a stable base of operations. So I argued that our strategy should be to put them on the defensive-
}

indirectly (through the states that gave them safe havens) and directly (whenever we had actionable intelligence). The emphasis on a global campaign was important, I believed, because striking only al-Qaida in Afghanistan would result in little more than causing the terrorists to shift their base to Pakistan, Somalia, Yemen, Sudan, or elsewhere." [35]

Rumsfeld was a strong believer in the "global campaign" against terrorism. $\mathrm{He}$ was an early advocate of expanding counterterrorism initiatives in Africa, calling for a systematic change in the military's strategy of engagement with Africa in 2003. [36]

As these programs grew, it became evident that EUCOM and CENTCOM were stretched for resources to manage them. Previously, both commands had focused mainly on their main geographic center, meaning Africa was often a 2nd or 3rd priority. OEF-TS and OEF-HOA demanded more attention. When speaking about the decision to establish AFRICOM, Theresa Whelan explained, "Africa's direct relevance to U.S. national security demanded that DoD re-think the Cold War based structure." [37]

$$
\begin{gathered}
\text { AFRICA'S RISING ECONOMIC } \\
\text { IMPORTANCE }
\end{gathered}
$$

While Africa was becoming more important in the Global War on Terrorism, the continent was also rising in economic importance. Throughout the 1990s and 2000s, U.S. and Chinese firms heavily invested in resource exploration, particularly in oil. In 1996, China acquired oil fields in Sudan that had been abandoned by the U.S. company Chevron because of the civil war. China developed the oil fields and discovered more oil reserves, attempting to revive Sudan's oil industry in the midst of 


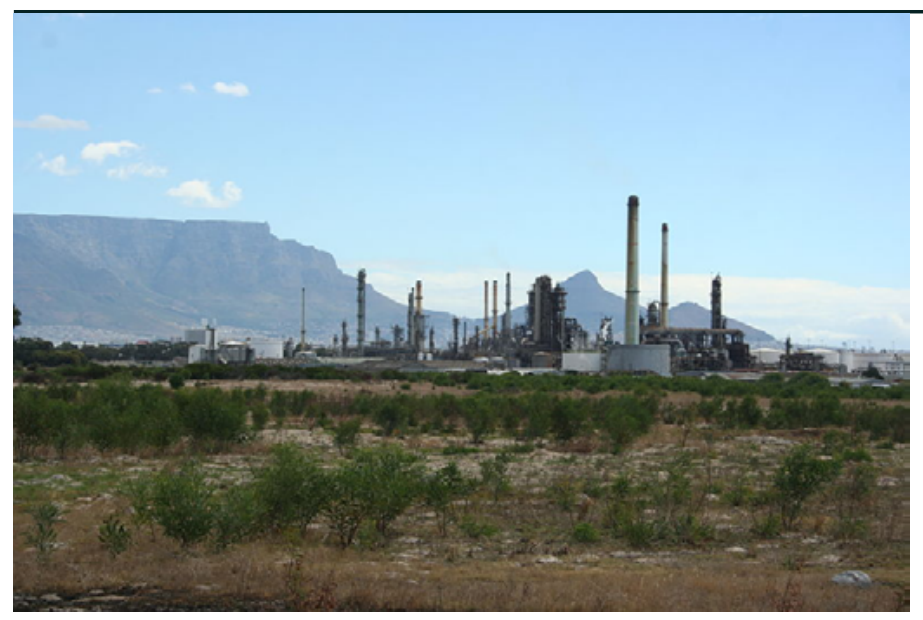

CHEVRON OIL REFINERY IN CAPE TOWN, SOUTH AFRICA

the civil war. Currently, China receives $1 / 3$ of its oil imports from Africa. [38] Sudan provides an estimated $5 \%$ of China's total oil imports. [39] In exchange, China is the largest supplier of military equipment to Sudan. This was a point of contention for China-U.S. policy during the Sudanese civil war when the U.S. wanted to impose harsh sanctions on the Sudanese government. [40]

Over the past decade, China has heavily invested in African oil, seeking to fulfill the growing energy demands of its population. In 2004 China obtained one fourth of its imported oil from Africa. [41] By 2011, this number had risen to one third and continues to grow. [42] African crude oil is especially attractive for China as it tends to be low in sulfur and high in quality. Chinese refineries often lack the capacity for heavier crude oil from the Middle East, which is high in sulfur. [43]

The African continent also possesses some of the world's largest reserves of mineral ores and precious metals. The Democratic Republic of Congo has $64 \%$ of the world's reserves of coltan, an ore used in the manufacture of electronic products, [44] along with a third of the world's cobalt reserves. [45] Sierra Leone, Angola, and
Botswana are all well known for their mining of diamonds. Gold, uranium, steel, platinum, and copper are among the many other resources found on the continent. Resources are a large part of many African economies, as they are exported throughout the world. As China has grown in manufacturing, its trade with Africa in mineral ores has increased. In 2010, China imported a total of $\$ 50.6$ billion dollars worth of minerals and $\$ 6.2$ billion dollars worth of metals from African countries. [46] China is now Africa's largest trading partner, having surpassed the U.S in 2009.

The U.S. has also heavily invested in African resources throughout the past decade. In addition to oil, the U.S. imports precious stones and metals ( $\$ 4.3$ billion dollars worth in 2011). [47] However, oil makes up the bulk of U.S. imports from the region, with $16.8 \%$ of imported oil coming from Africa. [48] In 1996, the major U.S. oil company ExxonMobil invested in oil exploration at the Gulf of Guinea, which is off the coast of West Africa and belongs to the country Equatorial Guinea. The Gulf of Guinea is considered the world's hottest oil exploration hotspot, as exploration continues to expand oil sources. [49] The Gulf is located off the coast of West Africa, starting 
south of Cote d'Ivoire and extending south to Angola. Like China, U.S. oil imports from Africa have grown significantly over the past several years, from $15 \%$ in 2004 to $22 \%$ in 2006. [50] In addition to the Gulf of Guinea, the U.S. imports oil from Nigeria and Angola. Angola is an important source of petroleum for both China and the U.S., but ChevronTexaco and Exxon Mobil remain its largest investors.

\section{PLANNING FOR AFRICOM BEGINS}

In the mid 2000s, after the start of the start of the Global War on Terrorism, the academic discussion over the UPC continued as more reports were published calling for a unified military command in Africa. [51] In 2006, EUCOM commanders noted to Congress that staff at the headquarters in Stuttgart, Germany were spending more than half of their time on African issues. This signaled a shift in the discussion about an Africa Command from the academic to the policy arena. [52] After spending time at CENTCOM's headquarters in Tampa, Rumsfeld realized that the command was too was overwhelmed, especially as it began planning for the Iraq war in 2002. [53] In July of 2006 during a routine annual briefing on potential changes to the UCP, Secretary of Defense Donald Rumsfeld and Joint Chief of Staff Peter Pace expressed interest in a change towards Africa. Rumsfeld directed the EUCOM commander to form a planning team to explore setting up a new command for Africa. Pace noted that there were several options on the table: a fully independent regional command similar to the current ones, a regional authority that answered to another command, or something in between. [54] For Rumsfeld, the key issues were how best to organize the command and integrate non-military agencies. [55] As the State Department has numerous counterterrorism initiatives in Africa, any new command would have to require interagency planning. From the start, AFRICOM was set up to be a different type of military command. According to General William "Kip" Ward, the commander of EUCOM at the time and leader of the planning team, "it's ok if it doesn't look like other COCOMs [combatant commands]." General Ward emphasized that the planning should aim for "innovative processes rather than a traditional military COCOM structure." [56]

At the Pentagon, Rumsfeld and Pace mentioned the EUCOM planning team during a Town Hall meeting in September. [57] This stirred much interest in the press, as a new command hadn't been created since CENTCOM in 1983. Soon after the Town Hall meeting, Rumsfeld was briefed by the EUCOM planning team. The team recommended setting up a full unified command for Africa, but with a nontraditional structure. EUCOM planners suggested that the command be "focused on traditional military tasks, as well as an emphasis on non-combat military roles such as capacity building and theater security cooperation." [58] To address Rumsfeld's concern about interagency cooperation, the team recommended the command integrate staff from non-military agencies into its leadership. Lastly, the team recommended the command's headquarters, along with five regional offices, be located in Africa "as a way to demonstrate long-term US commitment to Africa's security and stability." [59]

Rumsfeld agreed with the EUCOM team's conclusions, and advanced the planning for an Africa Command to the Pentagon. He approved the creation of an interagency Implementation Planning Team, to be headed by Admiral Robert Moeller. Admiral Moeller was a senior Navy official who was at that time Director for Strategy, 
EX-SECRETARY OF DEFENSE, ROBERT M. GATES, PRESENTS THE DEFENSE DISTINGUISHED SERVICE MEDAL TO OUTGOING COMMANDER OF AFRICOM,

GENERAL WILLIAM WARD,

DURING THE AFRICOM CHANGE OF COMMAND CEREMONY

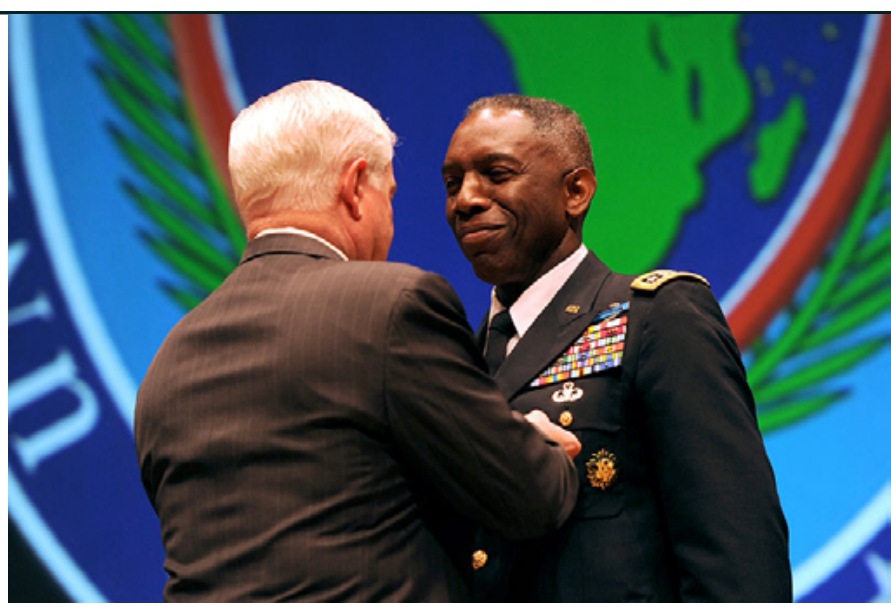

Plans, and Policy for CENTCOM. [60] Admiral Moeller's deputy for the team was Ambassador Robert Loftis from the State Department (DoS) [61], a career Foreign Service official who was a lead negotiator for status of forces agreements. From DoD, the team also included Theresa Whelan, Deputy Assistant Secretary of Defense for African Affairs, who had served in the Balkans Task Force as the NATO team chief during the Kosovo crisis. [62] In addition to DoS and DoD officials, there were representatives from USAID and the Joint Chiefs of Staff. [63] The purpose of the team was to work through November and outline the structure of a new command for Africa. Rumsfeld's instructions were for the command to have a staff that was half-military and half-civilian with a non-military deputy - essentially a mirror of the planning team. [64]

According to Claudia Anyaso, a member of the team from the African Affairs Bureau at DoS, the State Department supported the creation of an Africa Command. [65] In a speech at the WIIS-U.S. Army War College AFRICOM Conference, Anyaso outlined several reasons why the DoS supported AFRICOM. She pointed to a slide about AFRICOM saying, "at the top are the words, 'peace, stability, and prosperity,' the goals that we are all striving for." [66] According to Anyaso, AFRICOM and the DoS had shared goals and "AFRICOM's mission will support the secretary's diplomatic policies." Lastly, AFRICOM would result in increased interagency collaboration, which would "provide an opportunity for continuous dialogue so that there will be a greater understanding of upcoming issues and afford an opportunity for better planning."

The final structure of the command also included a position for USAID Senior Development Advisor, along with several more representatives in the Programs and Humanitarian Assistance divisions. [67] USAID supported the creation of AFRICOM, but with some reservations.

"...yet experience has also taught us that when we work with the military, maintaining the essential humanitarian and development character of USAID is vital. USAID coordination with DoD should not be perceived as contributing to specific military objectives, but rather as contributing to broader foreign policy goals." - Michael E. Hess, Assistant Administrator of Bureau for Democracy, Conflict and Humanitarian Assistance at USAID [68] WW 
There seemed to be some skepticism within USAID about the new command. Kate Almquist, who was the Sudan mission director and assistant administrator for Africa at USAID, stated that the initial decision was met with "grumpiness at spending staff time and program resources to help AFRICOM do work that it had minimal resources and no competency or experience to do."[69] Almquist agreed with the DoD's aim to increase interagency collaboration in AFRICOM's planning, saying organizational integration could help the bureaucracies coordinate strategies and efforts. However, she also concluded, "that does not mean either should attempt to do the other's job." [70]

\section{AFRICOM GOES PUBLIC}

Planning for AFRICOM moved along at a fairly rapid pace. The interagency planning team presented a final briefing to Rumsfeld at the end of November. [71] In early December, Rumsfeld announced he would be resigning. AFRICOM could have easily gotten lost in Rumsfeld's transition out of office, but he ensured the planning team's recommendation was forwarded to President Bush on December 15th, who approved creation of the command that same day. [72] AFRICOM was officially announced on February 6, 2007 by new Secretary of Defense Robert Gates at a Senate Armed Services Committee hearing:

"The President has decided to stand up a new, unified combatant command, Africa Command, to oversee security cooperation, building partnership capability, defense support to nonmilitary missions, and, if directed, military operations on the African continent. This command will enable us to have a more effective and integrated approach than the current arrangement of dividing Africa between Central Command and European Command, an outdated arrangement left over from the Cold War." Robert Gates [73]

Later that day, the White House issued a statement by President Bush:

"This new command will strengthen our security cooperation with Africa and create new opportunities to bolster the capabilities of our partners in Africa. Africa Command will enhance our efforts to bring peace and security to the people of Africa and promote our common goals of development, health, education, democracy, and economic growth in Africa." [74]

As discussion of AFRICOM moved from the Pentagon into the public sphere, DoD officials had to defend the new command, as the press asked, "Why now?" Reporters wrote about the increasing influence of China in Africa and the growing economic importance of oil and other resources when reporting about AFRICOM. Theresa Whelan attempted to quell these misconceptions in a testimony for the House AFRICOM hearing. Whelan said the two biggest misconceptions about AFRICOM were that it would militarize U.S. foreign policy in Africa and that its primary purpose was to secure U.S. access to oil. Whelan countered these saying, "Africa Command is merely the logical next step in a course set almost a decade ago." [75] In regards to oil, she noted, "while Africa's growing importance as a global oil producer is certainly a factor in the continent's strategic significance, it was not, as has been explained previously in this paper, the rationale for the creation of AFRICOM." [76]

However, Whelan's reassurance did little to lessen controversy over AFRICOM in the media, especially as writings by 


AS DISCUSSION
OF AFRICOM
MOVED FROM
THE PENTAGON
INTO THE
PUBLIC
SPHERE, DOD
OFFICIALS HAD
TO DEFEND THE
NEW COMMAND,
AS THE PRESS
ASKED, “WHY
NOW?”

neoconservative groups such as the Heritage Foundation were publicized. In an NBC Frontline episode on Bush's decision to create the new command, Christopher Moraff brought up a Heritage Foundation policy backgrounder written in 2006 about China's increasing influence in Africa:

"The United States must be alert to the potential long-term disruption of American access to important raw materials and energy sources as these resources are 'locked up' by Chinese firms." [77]

According to Moraff, "Neoconservative groups call China's growing relationship with Africa 'alarming' and want a response." [78] Moraff saw Bush's decision to create AFRICOM as a response to pressure from neoconservatives to address China. Moraff further pointed out that the announcement of AFRICOM's creation came a week after Chinese President $\mathrm{Hu}$ Jintao had landed in Cameroon to start series of meetings with African leaders where he signed cooperation agreements and pledged to double China's assistance to Africa. [79]

The Search for a Headquarters
The DoD's search for a command headquarters in Africa caused additional negative publicity. The interagency implementation planning team had agreed with the original EUCOM committee's recommendation that the command's headquarters and regional offices be located in Africa. Further, in the White House announcement, Bush said the U.S. would work with African partners to find a location for the headquarters. This proved to be harder than the DoD had anticipated, as the response from African leaders was less than welcoming.

Within just a few months of the new command's announcement, it became apparent that only one African leader, President Ellen Johnson Sirleaf of Liberia, had welcomed an AFRICOM headquarters. Even within Liberia there was harsh resistance from the public. According to Professor Theo Neethling at Stellenbosch University in South Africa, the response to AFRICOM was "a mixture of anticipation, trepidation, suspicion, skepticism, and condemnation." [80] South Africa, thought to be one of the U.S.'s closes allies in Africa, was critical of the new command, with the Defence Minister Mosiuoa Lekota saying, "The United States Africa Command 
DESPITE AFRICOM'S ROCKY

RECEPTION BY THE MEDIA, THE

COMMAND HAS BEEN PRAISED

FOR ITS MANAGEMENT OF THE

EARLY STAGE IN THE LIBYA

INTERVENTION, CALLED

OPERATION ODYSSEY DAWN

(AFRICOM) should stay out of the African continent." Lekota explained to BBC that South Africa's main issue with AFRICOM wasn't the command itself, but instead its location on the continent. [81]

In April, senior DoD officials traveled to Africa to discuss the command with African leaders. [82] DoD spokesman Ryan Henry said the discussions had been "fruitful" and denied that they had tried and failed to find a proper location for the headquarters. [83] In October of 2007, shortly after AFRICOM was activated, General Ward, who had been appointed the commander of AFRICOM, made the decision to indefinitely postpone the question of the headquarter location because it "distracted from the primary mission of the command, which was to build relationships and sustained programs." [84] Currently, the command headquarters is still located alongside EUCOM in Stuttgart, Germany, with no regional sub-offices in Africa.

\section{EPILOGUE: WhAT HAS AFRICOM DONE?}

"United States Africa Command, in concert with other U.S. government agencies and international partners, conducts sustained security engagements through military-to-military programs, militarysponsored activities, and other military operations as directed to promote a stable and secure African environment in support of U.S. foreign policy." - AFRICOM mission statement May 2008 [85]

Five years later, with headquarters still in Germany, what has the young command actually accomplished? AFRICOM's starting budget in 2007 and 2008 was a combined $\$ 125$ million, although President Bush had asked for more. In fiscal year 2009, AFRICOM's budget increased to \$310 million, and in 2010 it kept fairly steady at $\$ 302$ million. [86] The budget covers the command's operations, maintenance of its headquarters, the salaries of civil service employees assigned to the headquarters, and the costs of conducting AFRICOM's various military-to-military programs. [87]

AFRICOM's programs are carried out by its small staff of about 2,000, the majority of whom work in the Stuttgart headquarters, and around 50 civilian staff from other U.S. government bureaus. The command has taken over the OEF-TS and OEF-HOA operations, which include responsibility for the CJTF-HOA. Funding for the CJTF-HOA and its base in Djibouti, 
however, comes mostly from the Navy, [88] and includes troops from allied forces as well. The Task Force is headquartered at Camp Lemmonier, a U.S. base that is leased from the Djibouti government. There are about 3,500 U.S. and allied personnel and DoD contracters. The Task Force has continued its main operations of training the Navies of HOA countries for maritime security. AFRICOM also created the Africa Partnership Station (APS), a program to further strengthen maritime security through training and joint exercises, infrastructure building, and the facilitation of cross-border collaboration. In 2010,APS worked with 17 African countries. In addition to the U.S. Navy, the APS program has included military professionals from European countries and Brazil. AFRICOM also coordinates a third maritime security-training program with the U.S. coast guard. [89]

OEF-TS has also continued to train and equip the national militaries of its ten partner countries (Algeria, Burkina Faso, Mali, Mauritania, Chad, Morocco, Niger, Nigeria, Senegal, and Tunisia). The main goal of this training is to build the military's capacity to deter the illegal drug and arms trade in the Sahel/Sahara region and to prevent terrorists from establishing safehavens. In 2011, OEF-TS was the U.S. government's 3rd highest counterterrorism priority. The operation works with the State Department's International Military and Education Training (IMET) program, which in 2009 trained about 900 military students from Africa both in the U.S. and in Africa. This program recently came into some controversy when a soldier who had been trained by IMET led a military coup in Mali in March of 2012. [90]

AFRICOM has further received negative publicity when General Kip Ward was demoted due to allegations of "lavish spending." Ward had already retired and
General Carter F. Ham had taken over, however, the DoD led an investigation into Ward's spending on trips to Africa and has ordered him to repay $\$ 82,000$ to the government. [91]

Despite AFRICOM's rocky reception by the media, the command has been praised for its management of the early stage in the Libya intervention, called Operation Odyssey Dawn. This was AFRICOM's first military operation. The command coordinated the combat operations of eleven U.S. warships and dozens of aircrafts, fired over 100 tomahawk cruise missiles, and attacked 45 ground targets. [92] The operation ended after twelve days when NATO took over with a longer-term operation. AFRICOM's successes, however, received political backlash from several African countries due to the command's direct role in the intervention. After the hesitant reception to the new command in Africa, AFRICOM had tried to lay low and build the trust of its African partners. According to Jonathan Stevenson of Foreign Affairs magazine, "AFRICOM will have a hard time reestablishing its bona fides with African governments, which were fairly tenuous even before the Libyan intervention." [93]

In addition to the several programs and interventions mentioned, AFRICOM leads a number of smaller programs, such as Operation Onward Liberty, which provides U.S. military mentors to advise the Liberian Armed Forces, [94] and the U.S. LRA task force, which consists of 100 advisors to support regional effort against the LRA. [95] The command also assists with delivery of humanitarian assistance and emergency aid, and has recently incorporated disaster response into its training of African forces. [96]

Currently, terrorist activity in the Sahara/Sahel region and the Horn of Africa remains a key security challenge for African 
REGIONAL

STRUCTURE BEFORE

AFRICOM

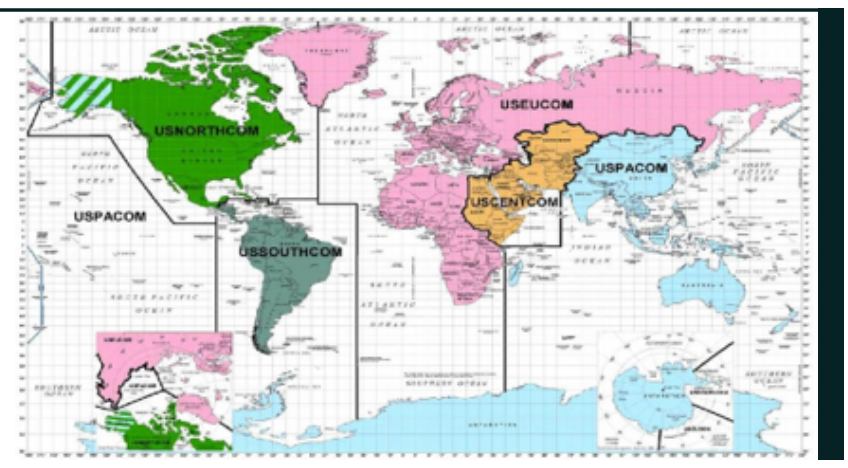

countries and the U.S. The radical terrorist groups Al-Shabaab in Somalia, AQIM in North Mali, and Boko Haram in Nigeria pose the biggest threats to U.S. security interests in Africa. [97] Since AFRICOM's establishment, these groups have gained even more power, particularly in Mali, where AQIM-affiliated rebel groups have overtaken the northern half of the country. The command proved its military capacity during the Libya intervention; however, the success of its capacity-building programs is open to debate.

UNIFIED COMMAND

PLAN AFTER

AFRICOM'S

CREATION

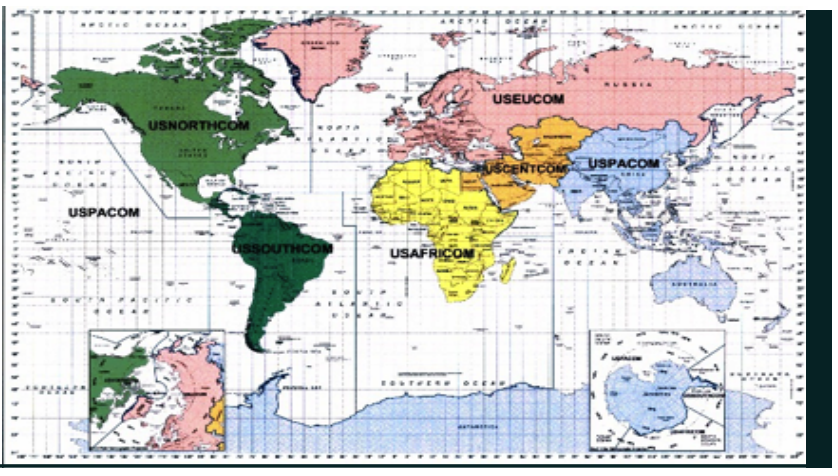

